\title{
Puff Volume Measurement as affected by Temperature with Various Cigarette Types and Modes of Smoking (an in vitro study) *
}

\author{
by Andrew R. Guyatt and Andrea G. Baldry \\ The Midhurst Medical Research Institute, Surrey Research Park, Guildford, Surrey, England
}

\section{SUMMARY}

An in vitro evaluation was made of the measurement of puffing behaviour using an orifice-plate cigarette holder. Four brands of cigarettes were compared ranging in tar yield from 4 to $16 \mathrm{mg}$, and each was studied with two puff profiles, the "early triangle" and the "square wave" pattern. Two flow rates were used for each profile giving maximum flows of 25.7 and $37.0 \mathrm{ml} \mathrm{s}^{-1}$ (early triangle) and 12.0 and 36.7 (square wave), respectively, and four puff volumes, i.e. 15, 40, 65, and $90 \mathrm{ml}$ for each profile/flow combination. Forty-eight cigarettes of each type were smoked (three for each profile/flow/volume combination).

The studies emphasize the need for careful calibration of the alinear flow system and the value of reference volume standards. When calibrated with air, volume measurements on smoke at ambient temperature were overestimated by an average of $1.4 \%$. An average overestimation of $1.2 \%$ was seen per $1{ }^{\circ} \mathrm{C}$ rise in temperature. This rise in temperature occurred in the last few puffs, and was mainly influenced by the puff volume. There was much less difference when subdividing the data according to cigarette type, the early triangle or square wave profiles, or the two flow rates. With puff volumes of $15 \mathrm{ml}$ there was virtually no temperature rise, and except at $90 \mathrm{ml}$ the effect was only important in the last $20 \%$ of the smoking period.

\section{ZUSAMMENFASSUNG}

Es wurde in vitro eine Untersuchung zu Studien von Rauchgewohnheiten durchgeführt, bei denen ein Zigarettenhalter mit Lochplatte verwendet wurde. Vier $\mathrm{Zi}$ garettenmarken mit Kondensatwerten zwischen $4 \mathrm{mg}$ und $16 \mathrm{mg}$ wurden miteinander verglichen, wobei jeweils der Einfluß zweier Zugprofile, des linksseitig verschobenen Dreieckprofils (early triangle) und des

\footnotetext{
* Received: 9th February 1987 - accepred: 27th January 1988.
}

Rechteckprofils (square wave), untersucht wurde. Für jedes Profil wurden zwei Strömungsgeschwindigkeiten angewendet, wodurch sich für die Durchflußmengen die Hōchstwerte $25,7 \mathrm{ml} \mathrm{s}^{-1}$ bzw. $37,0 \mathrm{ml} \mathrm{s}^{-1}$ (Dreieckprofil) und $12,0 \mathrm{ml} \mathrm{s}^{-1} \mathrm{bzw} .36,7 \mathrm{ml} \mathrm{s}^{-1}$ (Rechteckprofil) und entsprechend der jeweiligen Zugprofil/ Strömungsgeschwindigkeit-Kombination die vier Zugvolumina von $15,40,65$ und $90 \mathrm{ml}$ ergaben. Je Zigarettenmarke wurden 48 Zigaretten verraucht (jeweils drei bei den verschiedenen Kombinationen von Zugprofil, Strōmungsgeschwindigkeit und Zugvolumen).

Die Untersuchungen machen deutlich, daß genormte Referenzwerte für das Zugvolumen sowie eine sorgfältige Kalibrierung des nichtlinearen Strōmungssystems in diesem Zusammenhang wichtig sind. Bei Kalibrierung der Apparatur mit Luft wurden die Rauchzugvolumina unter Umgebungstemperaturbedingungen durchschnittlich um $1,4 \%$ zu hoch bemessen. Bei erhöhter Temperatur erwiesen sich die Meßwerte je $1^{\circ} \mathrm{C}$ als durchschnittlich um $1,2 \%$ zu hoch. Ein solcher Temperaturanstieg war während der letzten Rauchzüge zu beobachten und wurde vor allem durch das Zugvolumen bewirkt. Die Unterschiede waren wesentlich geringer, wenn die Meßwerte den jeweiligen Zigarettentypen, Zugprofilen und Strömungsgeschwindigkeiten zugeordnet wurden. Hinsichtlich einer Erhöhung der Temperatur hatte das Zugvolumen bei $15 \mathrm{ml}$ praktisch keinen Einfluß und war außer bei $90 \mathrm{ml}$ nur während der letzten $20 \%$ des Abrauchvorganges von Bedeutung.

\section{RESUME}

Une évaluation in vitro de la façon d'inhaler la fumée a été réalisée en utilisant un porte-cigarette avec une plaque percée d'un orifice. Quatre marques de cigarettes contenant de 4 à $16 \mathrm{mg}$ de goudron ont été comparées les unes aux autres, chacune d'elles étant étudiée en considérant deux profils de bouffée: «early triangle» et ssquare wave*. Deux débits d'inhalation ont été uti- 
lisés pour chacun de ces profils, soit respectivement des débits maxima de 25,7 et $37,0 \mathrm{ml} \mathrm{s}^{-1}$ (early triangle) et de 12,0 et $36,7 \mathrm{ml} \mathrm{s}^{-1}$ (square wave). Il en a résulté quatre volumes de bouffée: $15,40,65$ et $90 \mathrm{ml}$ pour chaque combinaison profil/débit. 48 cigarettes de chaque marque ont ainsi été fumées (trois pour chacune des différentes combinaisons profil/débit/volume).

Ces études montrent nettement l'importance qui revient ici aux valeurs de référence prises pour le volume des bouffées ainsi qu'à un calibrage soigneux du système de débit non-linéaire. Lorsque le calibrage du système a été effectué avec de l'air, les mesures des volumes de fumée à la température ambiante ont conduit à des résultats surestimés en moyenne d'environ 1,4\%. A température plus élevée, les valeurs mesurées se sont avérées en moyenne de $1,2 \%$ trop élevées par ${ }^{\circ} \mathrm{C}$ d'augmentation de température. Cette élévation de température, qui a été observée pendant les dernières bouffées, dépend surtout du volume de la bouffée. Les différences sont apparues nettement plus faibles lorsqu'on a classé les résultats en fonction du type de cigarette, du profil de bouffée et du débit respectifs. En ce qui concerne l'élévation de température, l'effet du volume ne se fait pratiquement plus sentir pour une valeur voisine de $15 \mathrm{ml}$ et, à l'exception du volume de $90 \mathrm{ml}$, il n'est important que pendant le dernier cinquième de la durée de l'opération.

\section{INTRODUCTION}

Puffing behaviour during cigarette smoking can be measured using an external holder, with a resistive element such as an orifice (1), a system which has found wide acceptance. It has a small dead space volume $(1.15 \mathrm{ml}$ including mouth piece), negligible resistance at low flow rates (about $0.03 \mathrm{kPa}$ at $17.5 \mathrm{ml} \mathrm{s}^{-1}$ with a $2 \mathrm{~mm}$ orifice), and is not easily blocked with tar. However, the differential pressure varies according to the square root of the flow rate, necessitating linearization before analysis. The system is insensitive at low flow rates so that the process of integration to obtain puff volumes is more difficult than with a linear device.

Differential flow meters are affected by the density and viscosity of the measured gas and are normally calibrated on room air as a standard. Smoke measurement is complicated since its chemical composition and temperature vary with the length of the cigarette. The composition effects seem very small. At room temperature, measurements made on smoke are only about $3 \%$ greater than on air $(2,3)$. Temperatures of over $800^{\circ} \mathrm{C}$ have been measured in the burning coal of the cigarette $(4,5,6)$, although within 20 or $30 \mathrm{~mm}$ of this point the temperature approaches ambient levels $(2,5)$. In an in vitro study (3), temperatures of $80^{\circ} \mathrm{C}$ were observed in the filter during a final puff of $40 \mathrm{ml}$ or above, and this was associated with an overestimate of up to $16.8 \%$ in the volume measurements. In this study only one type of cigarette was used with a tar yield of over $16 \mathrm{mg}$, and the results might differ with low tar brands where the smoke is diluted with room air. Also the puffs were produced manually with a glass syringe so it was impractical to explore differences in the form of the puff profile or flow rate. Tar and nicotine deliveries are altered by a different puff profile (7), and this could also affect the smoke temperature.

We have been concerned with these problems in connection with a study of 75 volunteers seen on six occasions each. On each visit the subjects smoked a cigarette through an orifice holder but without smoke temperature measurements (unpublished data). Although each subject kept to the same type of cigarette throughout, there were wide variations between individuals in the brand chosen and the pattern of smoking.

The present study investigated these effects. An extended calibration routine monitored the linearization process and provided volume standards. We then simulated smoking with an in vitro study involving four brands of king-size cigarettes ranging from low to middle tar delivery. For each brand we compared two discrete puff profiles, the "early triangle" with a rapid initial flow rate which declines steadily, and the "square wave", where flow remains constant (these profiles correspond to the majority of patterns we observed in human smoking). For each profile we compared two different flow rates and four different puff volumes.

\section{METHODS}

\section{Instrumentation}

The cigarette holder was based on a published design (1), but with a $2 \mathrm{~mm}$ orifice, made of brass with a plastic mouthpiece (Fig. 1, top panel). Differential pressures were measured across the orifice, giving the flow, and also at the port nearest the cigarette against atmosphere, giving the draw pressure * of the cigarette. Variable reluctance transducers (Validyne MP45, with Hewlett-Packard 8805B carrier amplifiers) were used. The flow signal was linearized electronically and both signals digitized at $20 \mathrm{~ms}$ intervals using a microcomputer (Kontron Psi 80 D), programmed using FORTRAN IV. The system was shown to be linear between 8.3 and $53.3 \mathrm{ml} \mathrm{s}^{-1}$ when comparing the output against flow rates measured by a rotameter and applying regression analysis. Analysis of variance showed no significant reduction in the deviation from regression when substituting a second order polynomial for the linear equation (8).

The draw pressure signal was calibrated with a water manometer. The flow signal was calibrated against a reference capillary pneumotachograph which itself was calibrated against a volume standard (20 strokes of a $100 \mathrm{ml}$ syringe with data digitizing every $20 \mathrm{~ms}$ ). The results obtained by a pneumotachograph were compared with those of a rotameter over the flow range

\footnotetext{
* Pressure/flow ratio.
} 
8.33 to $166.7 \mathrm{ml} \mathrm{s}^{-1}$ and shown to be linear (8). The holder and pneumotachograph were then placed in. series and air was drawn through at rates varying between $O$ and $160 \mathrm{ml} \mathrm{s}^{-1}$. The calibration factor was taken as the slope of a linear regression between the signals, using up to 1000 values (the coefficient of correlation was always in excess of 0.999). The data were simultaneously displayed as an $x-y$ plot on the computer screen and the calibration rejected if this appeared abnormal. The puff volumes measurement $\left(V_{p}\right)$ was then simulated by using two volume standards. Air was drawn through the holder from glass syringes set to give strokes of 50 and $20 \mathrm{ml}$, with ten cycles in each case. The whole calibration was repeated if either $V_{p}$ value deviated more than $5 \%$ from predicted. The syringe settings were checked by weighing the quantity of distilled water displaced by ten strokes into weighed beakers and correcting water density for temperature.

During smoking the flow signal was displayed on the computer screen. The onset of puffing was inferred when the draw pressure exceeded a threshold of $0.3 \mathrm{kPa}$ for $300 \mathrm{~ms}$. In the in vitro studies, a control signal was generated at $20.5 \mathrm{~s}$ intervals, $5 \mathrm{~s}$ duration, using a digital to analogue channel to open a solenoid valve and initiate a puff. (A short interpuff interval was deliberately chosen to increase the number of puffs available for analysis.) Five puffs were recorded on the unlit cigarette and related to puffs $2-6$ after lighting to give a comparison of air and smoke measurements before the temperature had risen perceptibly. (A similar comparison was made using the 20 and $50 \mathrm{ml}$ reference of the calibration device with smoke collected during in vitro smoking.)

Temperature was measured by a thermocouple ( $K$ type, COMARK model 1624, wire diameter $0.2 \mathrm{~mm}$ ) inserted in the mouthpiece $10 \mathrm{~mm}$ behind the orifice (Fig. 1, top panel). It had a $90 \%$ response of $0.6 \mathrm{~s}$ and was calibrated against a mercury thermometer in water at two temperatures. The digitized signal was displayed on the screen and the peak value for each puff was recorded. The signal was monitored for $9 \mathrm{~s}$ after the start of each puff, but the peak always occurred within $3 \mathrm{~s}$. The holder was cooled after each cigarette by drawing room air through for several minutes. A Cambridge filter was inserted between the mouth piece and solenoid tap to protect the system from tar accumulation. The filter assembly was sealed with modelling clay and adhesive tape to prevent air leaks.

Two systems were used to generate puffs. For the early triangle (Fig. 2, top), a 1 or 21 flask was used in which a reduced pressure $\left(p_{f}\right)$ was achieved by applying suction while the solenoid was deactivated (Fig. 1, centre). The pressure was set using a column of water $(0.5$ or $1 \mathrm{~m})$ through which air bubbled when the suction exceeded the desired level, and the resulting pressure fluctuations from the bubbles were smoothed using a 471 capacity reservoir. On activation, the solenoid connected the flask to the cigarette assembly, producing a flow surge followed by a steady decline as the pressure approached atmospheric $\left(\mathrm{p}_{\mathrm{b}}\right)$. On deactivation, $\mathrm{p}_{\mathrm{f}}$ was

\section{Figure 1.}

In vitro smoking system. Top panel: holder assembly with thermocouple. and Cambridge filter used in all studies. Centre panel: system for producing early triangle puff profiles. Bottom panel: system for producing square wave profiles.
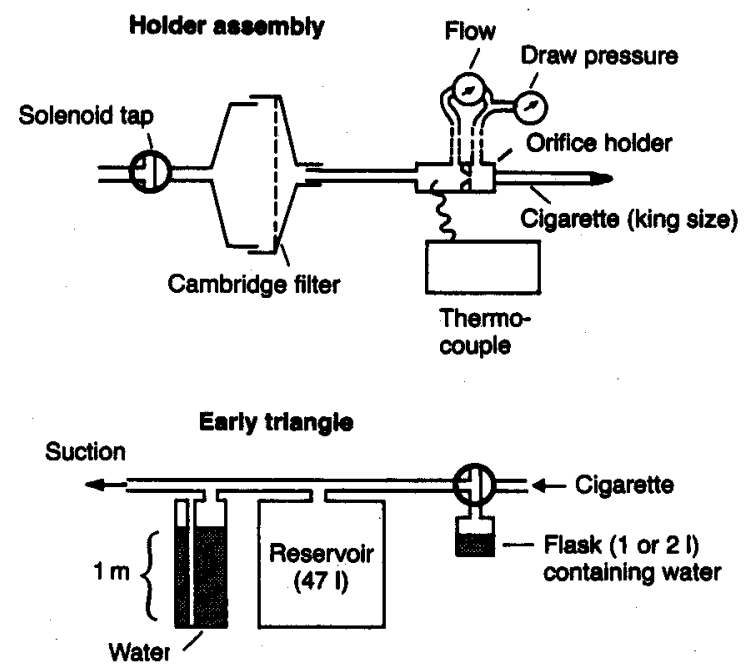

Square wave

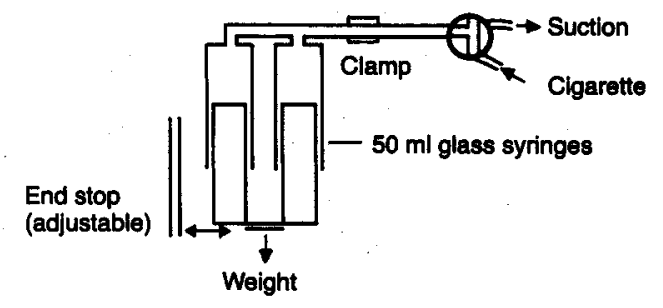

re-established for the next puff. The stroke volume, $V_{3}$, can be calculated from the equation:

$$
\mathrm{V}_{\mathrm{s}}=\mathrm{V}_{\mathrm{f}} \cdot\left(\mathrm{p}_{\mathrm{b}}-\mathrm{p}_{\mathrm{f}}\right) / \mathrm{p}_{\mathrm{b}},
$$

where $V_{f}$ was the volume of the air in the flask (adjusted by adding or removing water). The overall flow

\section{Figure 2.}

Flow proflles used. Top panel: early triangle, high and low flow rate with small and large volume for each. Bottom panel: square wave, similar flow and volume pattern.

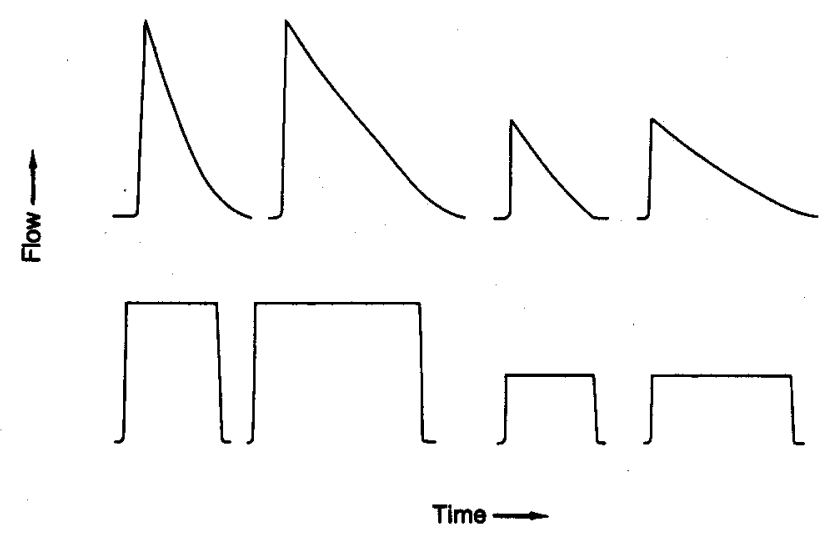


Table 1.

Comparison of puff volume $\left(V_{p}\right)$ measurements and assoclated measurements made on unilt clgarettes and from puffs 2 to 6 after lighting. Data subdivided according to test type, cigarette, and stroke volume $\left(V_{2}\right)$.

\begin{tabular}{l|c|c|c}
\hline Type of experiment & $\begin{array}{c}\text { Unlit } \\
\text { volume } \\
(\mathrm{ml})\end{array}$ & $\begin{array}{c}\text { Volume } \\
\text { of puffs } \\
2 \text { to } 6 \\
(\mathrm{ml})\end{array}$ & $\begin{array}{c}\text { Change } \\
(\%)\end{array}$ \\
\hline
\end{tabular}

Puff profile

Early triangle, fast

Early triangle, slow

Square wave, fast

Square wave, slow

mean

\section{Tar value}

T5 $V_{s}: 15 \mathrm{ml}$

T5 $\mathrm{V}_{\mathrm{s}}: 40 \mathrm{ml}$

T5 $V_{\mathrm{s}}: 65 \mathrm{ml}$

T5 $\mathrm{V}_{\mathrm{s}}: 90 \mathrm{ml}$

mean

T10 $V_{\mathrm{g}}: 15 \mathrm{ml}$

T10 $V_{\mathrm{g}}: 40 \mathrm{ml}$

T10 $\quad V_{\mathrm{s}}: 65 \mathrm{ml}$

T10 $\mathrm{V}_{\mathrm{s}}: 90 \mathrm{ml}$

mean

T14 $\mathrm{V}_{\mathrm{g}}: 15 \mathrm{ml}$

T14 $\mathrm{V}_{\mathrm{s}}: 40 \mathrm{ml}$

T14 $\mathrm{V}_{\mathrm{s}}: 65 \mathrm{ml}$

T14 $\mathrm{V}_{\mathrm{s}}: 90 \mathrm{ml}$

mean

T17 $\mathrm{V}_{\mathrm{s}}: 15 \mathrm{ml}$

T17 $\mathrm{V}_{\mathrm{g}}: 40 \mathrm{ml}$

T17 $\mathrm{V}_{\mathrm{s}}: 65 \mathrm{ml}$

T17 $\mathrm{V}_{\mathrm{s}}: 90 \mathrm{ml}$

mean

$\begin{array}{rrr}52.9 & 54.2 & 2.3 \\ 52.4 & 52.3 & -0.7 \\ 52.5 & 53.9 & 2.3 \\ \frac{52.3}{52.5} & \frac{53.5}{53.5} & \frac{1.6}{1.4}\end{array}$

$\begin{array}{rrr}15.2 & 15.3 & 0.2 \\ 39.4 & 39.2 & -0.5 \\ 65.6 & 65.1 & -0.8 \\ \frac{89.7}{52.5} & \frac{91.3}{52.7} & \frac{1.8}{0.2}\end{array}$

$15.0 \quad 15.0-0.5$

39.7

40.5

2.1

65.0

65.1

0.1

$\frac{90.8}{52.6} \quad \frac{93.6}{53.5} \quad \frac{3.1}{12}$

15.0

15.2

1.5

39.9

40.9

2.4

$\begin{array}{lll}64.2 & 65.9 & 2.7\end{array}$

$\frac{91.7}{52.5} \quad \frac{93.7}{53.9} \quad \frac{3.0}{2.4}$

$14.9 \quad 14.6 \quad-1.6$

$39.8 \quad 40.5 \quad 1.6$

$65.1 \quad 67.5 \quad 3.7$

$\frac{90.0}{52.4} \quad \frac{92.7}{53.8} \quad \frac{3.0}{1.7}$
Variation of stroke volume $\left(\mathrm{V}_{\mathrm{a}}\right)$

$$
\begin{aligned}
& V_{\mathrm{s}}: 15 \mathrm{ml} \\
& \mathrm{V}_{\mathrm{s}}: 40 \mathrm{ml} \\
& \mathrm{V}_{\mathrm{s}}: 65 \mathrm{ml} \\
& \mathrm{V}_{\mathrm{s}}: 90 \mathrm{ml}
\end{aligned}
$$

15.0

39.7

15.0

$-0.1$

65.0

40.3

1.4

90.4

92.8

2.7

\section{Mean values}

\begin{tabular}{llccr} 
Temperature & $\left({ }^{\circ} \mathrm{C}\right)$ & 25.9 & 26.4 & 1.8 \\
p $17.5^{\prime}$ & $(\mathrm{kPa})$ & 11.9 & 13.3 & 12.3 \\
Duration & $(\mathrm{s})$ & 2.33 & 2.52 & 7.5 \\
Mean flow & $\left(\mathrm{ml} \mathrm{s}^{-1}\right)$ & 23.6 & 22.4 & -5.5 \\
\hline
\end{tabular}

Table 2.

Analysis of temperature rise on last puff, number of puffe and butt length (I), subdividing data according to type of test, type

\begin{tabular}{|c|c|c|c|c|}
\hline T5 & $\mathrm{V}_{\mathrm{s}}: 15 \mathrm{ml}$ & 2.1 & 26.4 & 1.21 \\
\hline T5 & $\mathrm{V}_{\mathrm{s}}: 40 \mathrm{ml}$ & 12.2 & 20.1 & 1.23 \\
\hline T5 & $\mathrm{V}_{\mathrm{g}}: 65 \mathrm{ml}$ & 16.7 & 15.6 & 0.60 \\
\hline \multirow[t]{2}{*}{ T5 } & $\mathrm{V}_{\mathrm{g}}: 90 \mathrm{ml}$ & 23.9 & 13.3 & 0.94 \\
\hline & mean & 13.7 & 18.9 & $1: 00$ \\
\hline T10 & $V_{s}: 15 \mathrm{ml}$ & 1.3 & 26.3 & 0.63 \\
\hline T10 & $V_{s}: 40 \mathrm{ml}$ & 11.1 & 18.6 & 0.40 \\
\hline $\mathrm{T} 10$ & $\mathrm{~V}_{\mathrm{g}}: 65 \mathrm{ml}$ & 17.7 & 16.0 & 0.21 \\
\hline \multirow[t]{2}{*}{ T10 } & $\mathrm{V}_{\mathrm{g}}: 90 \mathrm{ml}$ & 22.1 & $\underline{13.3}$ & 0.29 \\
\hline & mean & 13.0 & 18.5 & 0.38 \\
\hline $\mathrm{T} 14$ & $V_{s}: 15 \mathrm{ml}$ & 1.9 & 26.5 & 0.48 \\
\hline T14 & $V_{s}: 40 \mathrm{ml}$ & 16.2 & 18.0 & 0.42 \\
\hline $\mathrm{T} 14$ & $\mathrm{~V}_{\mathrm{s}}: 65 \mathrm{ml}$ & 22.5 & 14.1 & 0.67 \\
\hline \multirow[t]{2}{*}{$\mathrm{T} 14$} & $\mathrm{~V}_{\mathrm{s}}: 90 \mathrm{ml}$ & 26.4 & 12.1 & 0.58 \\
\hline & mean & 16.8 & 17.7 & 0.54 \\
\hline T17 & $\mathrm{V}_{\mathrm{s}}: 15 \mathrm{ml}$ & 2.8 & 26.5 & 1.02 \\
\hline T17 & $V_{s}: 40 \mathrm{ml}$ & 14.9 & 17.7 & 1.12 \\
\hline $\mathbf{T}$ & $V_{s}: 65 \mathrm{ml}$ & 25.1 & 13.6 & -0.29 \\
\hline & $\mathrm{V}_{\mathrm{s}}: 90 \mathrm{ml}$ & 28.8 & $\underline{10: 9}$ & -0.40 \\
\hline & mean & 17.9 & 17.2 & 0.37 \\
\hline
\end{tabular}
of cigarette and puff volume $\left(V_{p}\right)$.

\begin{tabular}{l|c|c|c}
\hline Type of experiment & $\begin{array}{c}\text { Temperature } \\
\text { rise for } \\
\text { the last puff } \\
\text { ("C) }\end{array}$ & $\begin{array}{c}\text { Number } \\
\text { of } \\
\text { puffs }\end{array}$ & $\begin{array}{c}\text { Butt } \\
\text { length } \\
\text { (mm) }\end{array}$ \\
\hline Puff proflle & & & \\
Early triangle, fast & 14.2 & 17.8 & 0.46 \\
Early triangle, slow & 15.4 & 17.7 & 1.02 \\
Square wave, fast & 15.5 & 18.6 & 0.49 \\
Square wave, slow & 16.3 & 18.1 & 0.31 \\
\hline
\end{tabular}

\section{Tar value}

Variation of stroke volume $\left(V_{0}\right)$

$\begin{array}{lrll}\mathrm{V}_{\mathrm{s}}: 15 \mathrm{ml} & 2.0 & 26.4 & 0.83 \\ \mathrm{~V}_{\mathrm{s}}: 40 \mathrm{ml} & 13.6 & 18.6 & 0.79 \\ \mathrm{~V}_{\mathrm{s}}: 65 \mathrm{ml} & 20.5 & 14.8 & 0.30 \\ \mathrm{~V}_{\mathrm{s}}: 90 \mathrm{ml} & 25.3 & 12.4 & 0.35\end{array}$

F ratios and significance lovel

for one-way analysls of varlance (degrees of freedom: 3188)

Different tests

$$
0.34 \quad 0.24 \quad 2.50
$$$$
(p>0.25) \quad(p>0.25) \quad(p<0.1)
$$

Different cigarettes

$$
\begin{array}{lll}
2.72 & 0.91 & 2.23
\end{array}
$$$$
(p<0.05) \quad(p>0.25) \quad(p<0.1)
$$

Different volumes

$203.6 \quad 578.6 \quad 2.05$ $(p<0.005) \quad(p<0.005) \quad(p>0.1)$ 
rate was proportional to $\mathrm{p}_{\mathrm{f}}$ and set by the height of the water column.

The square wave pattern (Fig. 2, bottom) was produced using a dropping syringe system consisting of two $50 \mathrm{ml}$ glass syringes ganged together (Fig. 1, bottom). With the solenoid deactivated, the plungers were held at the top by suction. On activation, they were connected to the cigarette assembly and fell at a constant rate to give a square wave puff profile. $V_{s}$ was varied by a moveable end stop, and flow rate set by adding appropriate weights to the plungers or restricting the connecting tubing with a screw clip.

The square wave system was also used to look for other possible artefacts. If the temperature rose in the syringes during smoking, $\mathrm{V}$, would change so the thermocouple was placed in the inlet to the syringes to examine this with $V_{s}$ set to $90 \mathrm{ml}$. The effects of changing flow rate were studied with an unlit cigarette with $V_{s}$ set to $73.5 \mathrm{ml}$ and varying puff duration $\left(t_{p}\right)$ between 1.7 and $5.7 \mathrm{~s}$. Finally draw resistance $\left(\mathrm{p}_{17.5}\right.$, measured at $17.5 \mathrm{ml} \mathrm{s}^{-1}$ ) was varied between $0.82,1.26$ and $2.31 \mathrm{kPa}$ using different lengths of cellulose acetate filter and setting $V$, to 32 or $95 \mathrm{ml}$.

\section{Protocol}

Four nationally available brands of filtered king-size cigarettes with tar yields in the range 4-5, 9-10, 1314 , and $16-17 \mathrm{mg}$ (referred to here as T5, T10, T14, and T17) were purchased from a retail outlet. Fortyeight cigarettes of each type were used, in sets of 12 for low and high flow rates with the early triangle and square wave puff profiles, respectively. Calibrations were performed at least twice during each set of 12 readings which consisted of 3 groups of four $V_{3}$ settings of $15,40,65$, and $90 \mathrm{ml}$ in a randomized test order. For each test, $\mathrm{V}$, and flow rate were adjusted to be within $5 \%$ of the required level and five puffs were recorded on the unlit cigarette. It was lit with a match and smoked down to the overwrap and extinguished by being dropped into a tube containing dry ice. The butt length was measured between the overwrap and the mid point of the burnt area, being expressed as the average of the extreme values. In a few cases negative values were obtained, but even here the cigarette had not been consumed as far as the cellulose filter.

\section{RESULTS}

\section{Calibration}

Thirty-four separate calibrations were performed. The 20 and $50 \mathrm{ml}$ syringe tests gave mean values of 19.9 and $48.5 \mathrm{ml}$ (the true volumes as measured by water displacement were 19.6 and $49.4 \mathrm{ml}$ ) with coefficents of variation of $1.42 \%$ and $2.06 \%$, respectively. In the check on temperature in the syringes, no change was seen at the inlet during smoking suggesting that the stroke remained constant throughout. In the other checks, $V_{p}$ was found to decrease by $3.25 \%$ when $t_{p}$ was halved (doubling of flow rate), and increased by $5 \%$ when $\mathrm{p}_{17.5}$ was increased from 0.82 to $2.31 \mathrm{kPa}$. (Some of the latter effect could be explained by an increase in puff duration of $36 \%$.)

\section{Comparison of Air and Smoke}

The comparison of the measurements made before and after lighting the cigarette is summarized in Table 1. For all 192 studies, $V_{p}$ increased on average by $1.4 \%$ after lighting. The data were also subdivided according to puff profile, cigarette type (divided further according to $V_{s}$, and the pertinent mean values) and $V_{s}$ (mean values of all measurements). Analysis of variance showed significant differences between the mean values for the various cigarettes and between $V_{n}$, but not between the different types of puff profile, nor were there any significant interactions between any of the three factors. The rise in temperature during puffs 2 to 6 after lighting was $0.5{ }^{\circ} \mathrm{C}$ whilst there was a fall in the mean flow rate of $5.5 \%$ reflecting a $12.3 \%$ rise in $\mathrm{p}_{17.5}$. We estimated that these latter changes would only produce a rise in $\mathrm{V}_{\mathrm{p}}$ of $0.16 \%$. When $\mathrm{V}_{\mathrm{p}}$ was measured with the $20 \mathrm{ml}$ syringe on collected smoke, it was $2 \%$ higher than that obtained with air, but with the $50 \mathrm{ml}$ syringe, the volume measured was $1 \%$ lower with smoke.

\section{Change in Volume with Temperature}

The effects of a rise in temperature on the puff volume are shown in Fig. 3. The data from the lit cigarettes have been pooled, then subdivided into ten groups of

\section{Flgure 3.}

Effect of temperature rise on puff volume measurement. Data split into cells reflecting temperature change from unlit condition ( -4 to 0,0 to 4,4 to $8{ }^{\circ} \mathrm{C}$, etc.). Number of observations: 1403 , $1306,248,177,128,88,55,42,7$, and 12 respectively.

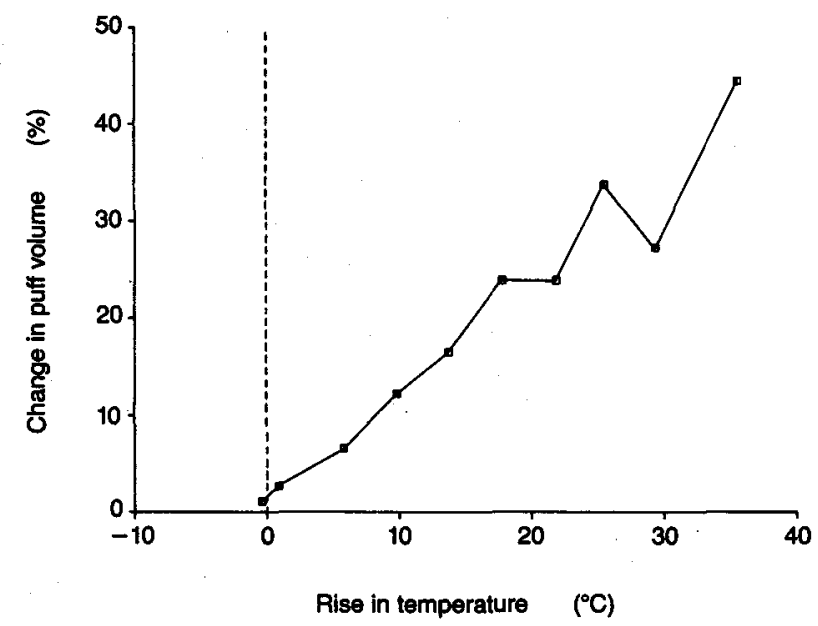


$4^{\circ} \mathrm{C}$ increments ( -4 to 0,0 to $+4^{\circ} \mathrm{C}$, etc.) according to the rise in temperature. The mean temperature for each cell is shown on the $\mathrm{x}$-axis. The $\mathrm{y}$-axis shows the mean $V_{p}$ for each cell expressed as a percentage of the unlit values. The slope of the best straight line through the $V_{p}$ vs. $T$ data indicates that $V_{p}$ rises by $1.2 \%$ per $1{ }^{\circ} \mathrm{C}$. (The last two cells, with temperature above $28^{\circ} \mathrm{C}$, were ignored since they only contained 7 and 12 values, respectively.)

\section{Temperature Rise}

We first considered the extreme case of the temperature on the last puff; these data are summarized in Table 2, together with average number of puffs taken and butt length, subdivided in the same way as in Table 1 . There was little effect of subdividing by flow profile or cigarette type (although analysis of variance showed a significant difference between the cigarettes as regards the temperature on the last puff). However there was a highly significant increase in temperature and reduction in puff number at the higher $\mathrm{V}_{s}$. Two-way analysis of variance also showed a significant interaction for temperature between cigarette type and $V_{s}$ at the $5 \%$ level. There were no significant differences in butt length for any analysis.

We next examined temperature changes over the whole smoking process, by pooling the data in four groups according to $\mathrm{V}_{\mathrm{s}}$ (Fig. 4). For each individual test, the total smoking time was divided into ten equal periods, shown on the $\mathrm{x}$-axis, and the data for each puff allotted to the appropriate period. A mean value of temperature $w$ as then derived for each period ( $y$-axis). There was a very clear separation between the results for the different $V_{s}$ groups, ranging from virtually no change at $15 \mathrm{ml}$ to marked increase from almost the beginning of smoking for the $90 \mathrm{ml}$ data.

\section{Figure 4.}

Change in temperature during smoking of clgarettes. Data pooled according to puff volume. Independent variable: fraction of time cigarette was lit.

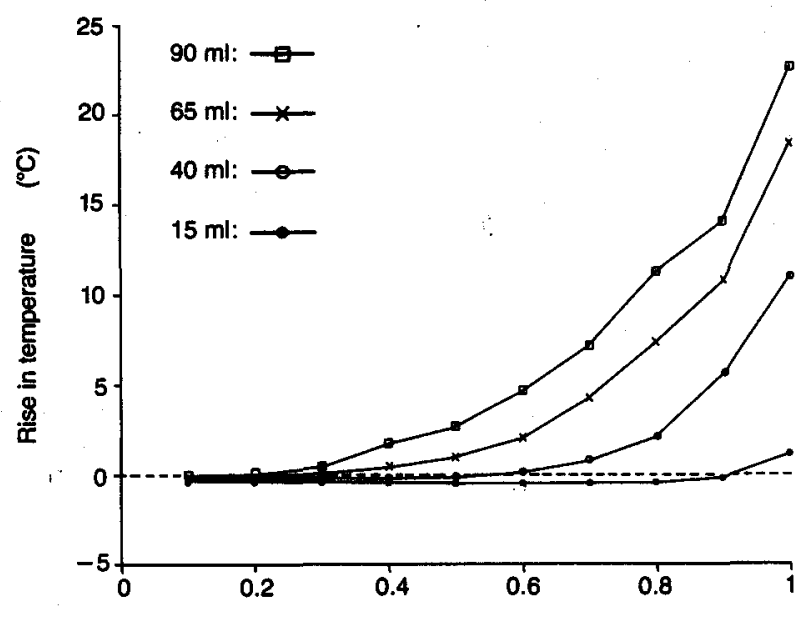

Time of smoking expressed as a fraction of the total time

\section{DISCUSSION}

The most important potential source of errors with this system appears to stem from the alinearity of the flow signal, making the adjustment of the equipment more critical than with conventional linear devices. In this context, we found our extended calibration system very useful with its visual check on the linearization process before and its test of the precision of the calibration using the reference volumes. The $V_{p}$ values agreed well with the predicted volumes with small coefficients of variance, but the $50 \mathrm{ml}$ values were proportionately less than those at $20 \mathrm{ml}$. This suggests that there was a slight residual error in the linearization process, with flow being underestimated at higher levels. It would account for the tendency of $V_{p}$, measured at constant $V_{s}$, to fall as $t_{p}$ decreases (mean flow rate increases).

This type of error is likely with any orifice flow meter since it is difficult to make a system which conforms precisely to the square root relationship. However it will have a minor effect on comparative measurements made within individuals; smokers are very consistent in the puff flow rates they use, for instance in these 450 studies the peak flow only varied on average by about $0.2 \%$ in the course of smoking a single cigarette (unpublished data). Puff volume does normally fall during the smoking of a cigarette but this is due to a decrease in duration. In these $\mathbf{4 5 0}$ studies, $\mathrm{V}_{\mathrm{p}}$ fell on average by $44.4 \%$ and duration by $43.9 \%$. Similar falls in puff volume and duration have been described $(9,10)$. Therefore for each subject alinearity of the flow device will tend to produce a constant error.

We confirmed earlier observations $(2,3)$ of small differences between flow measurements made on air and cool smoke. The detailed comparison using data from the unlit cigarette and from puffs 2-6 suggested a systematic average overestimate of $1.4 \%$ and that any differences due to the type of test, the cigarette used, or $\mathrm{V}_{s}$ are too small to be of practical importance. The short study with collected smoke gives slightly different results but here too the effect is very small.

Temperature has a marked effect on the measured puff volume (Fig. 3 ), with an average increase of about $1.2 \%$ per $1^{\circ} \mathrm{C}$ at constant stroke in the present system. However, this will only affect the last few puffs on a cigarette and we were concerned to see what was the overall effect on the measurements. We began by examining the relative importance of the various factors by looking at the extreme case of the last puff and we were able to disregard the trivial effects due to different puff profiles and flow rates. There was some effect from using different cigarettes and the lowest temperatures were seen in the low tar cigarettes in which, for a given puff volume, a smaller proportion of air passed through the burning coal and in which there was a greater subsequent dilution of smoke with room air. Two important factors controlling ventilation are the porosity of the cigarette paper, particularly just behind the coal (11) and filter ventilation in the low tar cigarettes. The former mechanism hardly applies here, since large tem- 
perature rises are only seen on the last few puffs when the paper is almost burnt away.

However these effects are small compared with those of changing puff volume and for the rest of this discussion we have confined our attention to this latter effect. When the puff-by-puff temperature data were pooled in four groups according to volume (Fig. 4), the result was qualitatively similar to earlier work (3) but with lower values. This probably reflects the different site for the thermocouple behind the orifice rather than in the filter since we were concerned with temperature changes in the holder. The smoke therefore may be cooled by the holder before reaching the thermocouple, which itself may underestimate the peak temperature because of its speed of response. The error is one of proportionality since the relationship between temperature and error in the volume signal (Fig. 2) appears linear. However the factor of $1.2 \%$ error per ${ }^{\circ} \mathrm{C}$, cited above, may be larger than with other systems.

We used this result to develop a simple model to estimate puff-by-puff temperature in our 450 studies. We assumed a constant burn rate and first estimated the time that each cigarette would have taken to smoke down to the butt $\left(t_{b}\right)$ from the formula:

$$
t_{b}=t_{s} \cdot l_{r} /\left(l_{r}-l_{b}\right)
$$

where $l_{r}$ was the original tobacco rod length, $l_{b}$ was the butt length, and $t_{s}$ was the observed smoking time. $t_{b}$ was expressed as ten equal periods, and the rise in peak temperature $(T)$ for each puff calculated from the formula:

$$
T=f_{i} \cdot\left(V_{p}-15\right),
$$

where $f_{i}$ was one of ten factors ranging in value from 0 to 0.6 which expressed the relationship between $V_{p}$ and the temperature for period i. Since there was virtually no temperature change with $15 \mathrm{ml}$ puffs, this value was subtracted from $V_{p}$.

A corrected $V_{p}$ value was then calculated assuming the overestimate of $1.2 \%$ per ${ }^{\circ} \mathrm{C}$, and a mean value was obtained for each cigarette, excluding the first and last puffs. The average uncorrected value for all 450 studies was $47.3 \mathrm{ml}$ falling to $46.4 \mathrm{ml}$ after correction, a difference of $1.4 \%$. (In one exceptional case the difference was $10 \%$, but this subject had a very unusual smoking pattern taking puffs of almost $100 \mathrm{ml}$ until he had smoked down to the butt.)

We also examined the data from the last puff separately (Table 3), puff volumes, durations and maximum flow, comparing them with mean values from the rest of the cigarette and subdividing them into three groups according to butt length. When the subject smoked to within $5 \mathrm{~mm}$ of the overwrap, the final $\mathrm{V}_{\mathrm{p}}$ was only $71.6 \%$ of the mean as compared with $85.2 \%$ when the butt was $10 \mathrm{~mm}$ or more. This seemed to be due in part to a reduction in puff duration since maximum flow actually increased. If the subject smokes within $5 \mathrm{~mm}$ of the butt, he is likely to notice a considerable tempera-
Table 3.

Puff volumes $\left(V_{p}\right)$, durations $\left(t_{p}\right)$ and peak flows $\left(F_{\max }\right)$ on last puffe compared with mean values in $\mathbf{4 5 0}$ human smoklng

\begin{tabular}{|c|c|c|c|}
\hline $\begin{array}{l}\text { Butt length } \quad(\mathrm{mm}) \\
\text { Number of measurements }\end{array}$ & $\begin{array}{l}0-5 \\
213\end{array}$ & $\begin{array}{l}5-10 \\
152\end{array}$ & $\begin{array}{l}>10 \\
85\end{array}$ \\
\hline Mean $V_{p}{ }^{*} \quad(m l)$ & 48.43 & 45.27 & 47.90 \\
\hline Last $V_{p} \quad(m l)$ & 34.23 & 35.32 & 40.53 \\
\hline Last $V_{p} /$ mean $V_{p} \quad(\%)$ & 71.63 & 79.49 & 85.21 \\
\hline Mean $t_{p} *$ & 2.09 & 2.08 & 2.14 \\
\hline Last $t_{p}$ & 1.38 & 1.41 & 1.61 \\
\hline Last $t_{p} /$ mean $t_{p} \quad(\%)$ & 67.2 & 69.6 & 75.5 \\
\hline Mean $F_{\max }$ * & 41.4 & 39.0 & 40.7 \\
\hline Last $F_{\max }$ & 43.7 & 43.3 & 44.8 \\
\hline Last $F_{\max } /$ mean $F_{\max } \quad(\%)$ & 106.2 & 112.4 & 111.7 \\
\hline
\end{tabular}
studles as a function of butt length $\left(l_{b}\right)$.

* Mean value excluding first and last puffs.

ture rise on the last puff and these data bear out a suggestion of $M$. Dixon (personal communication) that there is a very rapid response to a hot sensation. The data in this table are uncorrected for temperature so that the true differences between data at different butt lengths will be even greater.

We conclude that while the orifice cigarette holder is very convenient, considerable attention must be paid to calibration routines to produce accurate results. Measurements made on smoke are on average about $2.8 \%$ greater than those on air after taking composition and temperature differences into account. The rise in temperature seen at the end of smoking is little affected by the type of cigarette or form of the puff profile but is primarily a function of puff volume. The last puff may be reduced in size if the subject senses a marked temperature rise.

\section{REFERENCES}

1. Creighton, D. E., M. J. Noble and R. T. Whewell: Instruments to measure, record and duplicate human smoking patterns; in Smoking behaviour Physiological and psychological influences, edited by Raymond E. Thornton, Churchill Livingstone, Edinburgh, London and New York, 1978, pp. 277-288.

2. Rawbone, R. G., K. Murphy, M. E. Tate and S. $\mathrm{J}$. Kane: The analysis of smoking parameters - Inhalation and absorption of tobacco smoke in studies of human smoking behaviour; in Smoking behaviour - Physiological and psychological influences, edited by Raymond E. Thornton, Churchill 
Livingstone, Edinburgh, London and New York, 1978, pp. 171-194.

3. Woodman, G., S. P. Newman, D. Pavia and S. W. Clarke: Temperature and calibration corrections to puff volume measurements in cigarette smoking; Phys. Med. Biol. 29 (1984) 1437-1440.

4. Touey, G. P., and R. C. Mumpower: Measurement of the combustion-zone temperature of cigarettes; Tob. Sci. 1 (1957) 33-37.

5. Neurath, G., H. Ehmke and H. Schneemann: Über den Wassergehalt von Haupt- und Nebenstromrauch; Beitr. Tabakforsch. 3 (1966) 351 - 357.

6. Baker, Richard R.: Variation of the gas formation regions within a cigarette combustion coal during the smoking cycle; Beitr. Tabakforsch. Int. 11 (1981) 1-17.

7. Creighton, D. E., and P. H. Lewis: The effect of smoking pattern on smoke deliveries; in Smoking behaviour - Physiological and psychological influences, edited by Raymond E. Thornton, Churchill Livingstone, Edinburgh, London and New York, 1978, pp. 301-314.

8. Snedecor, G. W., and W. G. Cochran: Statistical methods, 6th edition; Iowa State University Press, Ames, Iowa, U.S.A., 1967, pp. 447-471.

9. Adams, L., C. Lee, R. Rawbone and A. Guz: Patterns of smoking - Measurement and variability in asymptomatic smokers; Clin. Sci. (Lond.) 65 (1983) $383-392$.
10. Woodman, G., S. P. Newman, D. Pavia and S. W. Clarke: Inhaled smoke volume, puffing indices and carbon monoxide uptake in asymptomatic cigarette smokers; Clin, Sci. (Lond.) 71 (1986) $421-427$.

11. Baker, Richard R.: Variation of sidestream gas formation during the smoking cycle; Beitr. Tabakforsch. Int. 11 (1982) 181-193.

\section{Acknowledgements}

We would like to thank Mr. C. Mills, Mr. A. Crisp, Mr, B. Kastell and Mr. S. Carver for technical belp and Professor G. Cumming for bis belp and encouragement.

Autbors' address:

The Midhurst Medical Research Institute, Surrey Research Park, 30 Occam Road Guildford, Surrey, GU2 SYW, England. 